\title{
Pengaruh Pelatihan Pasar Modal, Persepsi Mahasiswa, Modal Minimal dan Hubungan Pertemanan pada Minat Berinvestasi
}

\author{
Ida Bagus Putu Pramana Putra ${ }^{1}$ \\ Ni Luh Supadmi \\ ${ }^{1,2}$ Fakultas Ekonomi dan Bisnis Universitas Udayana (Unud), Bali, Indonesia \\ e-mail: gus2pram@gmail.com
}

\begin{abstract}
ABSTRAK
Tujuan dari penelitian ini adalah untuk mengetahui pengaruh Pelatihan Pasar Modal, Persespsi Mahasiswa, Modal Minimal dan Hubungan Pertemanan Pada Minat Berinvestasi. Penelitian ini dilakukan di Fakultas Ekonomi dan Bisnis Universitas Ekonomi Udayana pada mahasiswa S1 Akuntansi. Penelitian ini menggunakan teknik analisis regresi linear berganda. Dalam penentuan sampel penelitian ini menggunakan rumus Slovin untuk populasi yang diketahui. Dari hasil perhitungan didapatkan bahwa sampel berjumlah minimal 75 orang responden yang merupakan mahasiswa aktif angkatan 2015 dan telah menempuh mata kuliah teori pasar modal. Jenis data yang digunakan dalam penelitian ini adalah data kualitatif yang di kuantitatif, berupa hasil jawaban responden yang dinyatakan dalam bentuk angka-angka dari kuesioner yang diukur menggunakan skala Likert. Hasil analisis menunjukkan bahwa, modal minimal berpengaruh negatif pada minat berinvestasi dan pelatihan pasar modal, persepsi mahasiswa, hubungan pertemanan berpengaruh positif pada minat berinvestasi.

Kata kunci: Pelatihan pasar modal, persepsi mahasiswa, modal minimal, hubungan pertemanan, minat berinvestasi.
\end{abstract}

\begin{abstract}
The purpose of this study was to determine the effect of Capital Market Training, Student Perception, Minimum Capital and Friendship Relationships on Interest in Investing. This research was conducted at the Faculty of Economics and Business, University of Udayana Economics for Accounting S1 students. This study uses multiple linear regression analysis techniques. In determining the sample of this study using Slovin formula for known populations. The sample amounted to at least 75 respondents who were active students of the 2015 class and had taken capital market theory courses. Data used in this study is quantitative, in the form of the results of answers by respondents stated in the form of numbers from questionnaires measured using a Likert scale. The results of the analysis show that, minimum capital has a negative effect on investment interest and capital market training, student perceptions, friendship relations have a positive effect on investment interest.

Keywords: Capital market training, student perceptions, minimal capital, friendship, interest in investing.
\end{abstract}

\section{PENDAHULUAN}

Investasi adalah penanaman modal untuk satu atau lebih aktiva yang dimiliki dan biasanya berjangka waktu lama dengan harapan mendapatkan keuntungan di masa yang akan datang (Sunariyah, 2011). Salah satu tujuan melakukan investasi adalah untuk 
Ida Bagus Putu Pramana Putra dan Ni Luh Supadmi. Pengaruh ...

mendapatkan keuntungan. Dengan investasi, terutama di pasar modal, pelaku usaha akan mendapatkan modal dan dapat membuka lapangan usaha sehingga mengurangi pengangguran, menambah pemasukan pajak bagi negara dan mendorong daya saing. Investasi juga salah satu instrumen pembangunan yang dibutuhkan oleh suatu bangsa untuk meningkatkan kesajahteraan masyarakat. Pembangunan ekonomi merupakan salah satu fungsi dari investasi dalam artian penanaman modal atau faktor ekonomi yang paling esensial dan mudah diukur secara kuantitatif. Investasi merupakan faktor penggerak pembangunan ekonomi suatu Negara. Mayoritas masyarakat kita belum menyadari manfaat investasi, karena lebih mementingan untuk menjalani hidup mereka sekarang tanpa memikirkan hidup dimasa depan. Inflasi merupakan salah satu yang membuat seseorang membutuhkan investasi, karena inflasi mengakibatkan menurunnya nilai mata uang, untuk menghindarinya dengan cara berinvestasi.

Pasar modal memiliki peran penting dalam menunjang perekonomian suatu negara sebab pasar modal memiliki dua fungsi sekaligus, yaitu fungsi ekonomi dan fungsi keuangan. Pasar modal adalah tempat dimana bertemunya antara pihak yang memiliki kelebihan dana (investor) dengan pihak yang membutuhkan dana (perusahaan) dengan cara memperjual belikan sekuritas (Tandelilin, 2010). Hadirnya pasar modal memiliki peranan penting bagi para investor, baik investor individu maupun badan usaha. Mereka dapat menyalurkan kelebihan dana yang dimilikinya untuk diinvestasikan, sehingga para pengusaha dapat memperoleh dana tambahan modal untuk memperluas jaringan usahanya dari para investor yang berada di pasar modal. Investasi di pasar modal merupakan salah satu alternatif investasi yang mudah diakses oleh masyarakat luas semenjak dibukanya Bursa Efek Indonesia. 
Indonesia merupakan negara yang sedang berkembang dimana orientasi secara finansial masyarakatnya masih berjangka pendek atau dalam kategori saving society (menabung). Bila dibandingkan dengan negara maju orientasinya lebih ke jangka panjang atau dalam kategori investing society (investasi). (Rooij, Lusardi, \& Alessie, 2011) menganalisis hasil survey terhadap rumah tangga di Belanda dalam penelitiannya yang berjudul "Financial literacy and retirement planning in the Netherlands". Mereka menemukan bahwa orang-orang yang memiliki pengetahuan tentang keuangan cenderung menggunakan dananya untuk investasi yang direncanakan untuk masa pensiun. Rendahnya masyarakat yang berinvestasi di pasar modal Indonesia, disebabkan oleh beberapa faktor antara lain; Pertama, kurangnya pemahaman yang memadai mengenai cara bertransaksi di pasar modal. Kedua, adanya persepsi di masyarakat umum bahwa produk dan jasa pasar modal memiliki risiko tinggi. Ketiga, sebagian besar produk dan jasa pasar modal dimanfaatkan hanya oleh masyarakat kelas menengah atas. Kepala Eksekutif Hukum dan Perlindungan Konsumen Otoritas Jasa Keuangan (OJK) Tirta Segara mengungkapkan saat ini jumlah investor baru 1,4 juta orang. Namun, besarnya kelompok milenial yang terlibat merupakan kabar bagus. "Jumlah investor di Indonesia masih relatif kecil, kurang dari 1 persen dari penduduk. Baru 1,4 juta investor tetapi kira-kira setengahnya kelompok milenial, jadi banyak kelompok ini mulai investasi" (Tirto.id, 2018). Meski tumbuh dua digit, jumlah investor Indonesia relatif kecil jika dibandingkan dengan total penduduk 258 juta orang. Diadu dengan negara tetangga, Indonesia juga kalah dengan Malaysia dan Singapura yang memiliki 2,49 juta investor dan 1,5 juta investor. Menyikapi hal ini, Bursa Efek Indonesia (BEI) telah melakukan serangkaian upaya intensif untuk memperkenalkan pasar modal ke berbagai kalangan, salah satunya mahasiswa. Mahasiswa diharapkan sebagai agen perubahan 
Ida Bagus Putu Pramana Putra dan Ni Luh Supadmi. Pengaruh ...

(agent of change) masyarakat, dari masyarakat yang konsumtif menjadi masyarakat yang produktif dengan berinvestasi.

Meningkatkan minat masyarakat dengan edukasi adalah hal yang penting untuk dilakukan. Edukasi ini akan bermanfaat untuk meningkatkan jumlah peminat dengan menambah pengetahuan berinvestasi di pasar modal. Mata kuliah pasar modal, seminar-seminar investasi, pelatihan pasar modal akan menigkatkan kesadaran individu akan pentingnya berinvestasi, cara berinvestasi serta pemahaman tentang pasar modal yang perlu diketahui calon investor. Dalam rangka memajukan pasar modal Indonesia, maka Bursa Efek Indonesia bekerja sama dengan PT. Kustodian Sentral Efek Indonesia (KSEI), PT. Kliring Penjaminan Efek Indonesia (KPEI) beserta perusahaan-perusahaan sekuritas kemudian menyelenggarakan berbagai program edukasi seperti seminar, workshop, talk show interaktif dan Sekolah/Pelatihan Pasar Modal (SPM/PPM). Banyaknya calon investor yang ragu akan investasi membuat investasi dipandang sebelah mata. Setiap individu dapat mengetahui cara untuk berpartisipasi dalam pasar modal dengan adanya edukasi.

Mahasiswa dapat memulai untuk berinvestasi di beberapa sektor salah satunya di pasar modal demi memiliki kondisi finansial yang lebih baik di masa depan. Dana seringkali menjadi kendala utama seorang mahasiswa dalam melakukan investasi terutama mahasiswa yang mayoritas penghasilannya didapatkan dari kiriman orang tua. Program "Yuk Nabung Saham" dari pemerintah mencetuskan bahwa modal investasi minimal bagi mahasiswa untuk membuka akun rekening saham mengalami penurunan menjadi seratus ribu rupiah. Direktur Pengembangan BEI Nicky Hogan, mengatakan kampanye "Yuk Nabung Saham" secara konsisten digalakan sejak tiga tahun lalu 
melalui galeri investasi yang tersebar mulai dari kampus hingga pasar tradisional. Penyebab investor meningkat, kita ingat kampanye "Yuk Nabung Saham" yang bergulir bukan sesaat, tapi sudah tiga tahun dengan 387 galeri investasi dari target 400 hingga akhir tahun. Lewat program "Yuk Nabung Saham" Tidak hanya di kampus, tapi di kafe, pasar, hotel dan sudah mencakup seluruh provinsi, memudahkan calon investor, terutama generasi milenial untuk investasi dengan nominal mulai dari seratus ribu rupiah.

(Mumtaz, 2010) menyatakan, terdapat dua paradigma yang berlaku mengenai investasi di masyarakat. Pertama, investasi dianggap sebagai sebuah keinginan dan kedua investasi dianggap sebagai sebuah kebutuhan. Saat sebuah investasi dipandang sebagai sebuah keinginan, hal ini terjadi saat seseorang memiliki kelebihan uang, maka uang tersebut akan disimpan sebagai tabungan dari pada digunakan untuk berinvestasi. Pemilik uang tersebut baru akan menggunakan uang tersebut untuk kepentingan investasi ketika ia memiliki minat untuk menyalurkannya ke instrumen investasi. Kedua, investasi dianggap sebagai sebuah kebutuhan. Saat seseorang sedang memiliki kelebihan uang, maka kelebihan uang itu akan langsung digunakan untuk kepentingan investasi dibandingkan untuk ditabung. Mahasiswa pun demikian, yang menganggap investasi ini sebuah hal yang penting akan mengganggap sebagai sebuah kebutuhan, mahasiswa yang tidak menganggap investasi sebagai kebutuhan mungkin lebih menyukai hal yang lebih bersifat memenuhi keinginan atau konsumtif. Mahasiswa tentunya juga memiliki persepsi tersendiri terhadap investasi. Persepsi mahasiswa dalam berinvestasi berbedabeda, seperti menganggap investasi sebagai hal yang penting dilakukan sejak dini ataupun sebagai hal yang dirasa belum perlu untuk dilakukan.

Hubungan pertemanan juga menjadi faktor dalam menumbuhkan minat mahasiswa berinvestasi, sebagaimana kita ketahui seorang individu cenderung 
Ida Bagus Putu Pramana Putra dan Ni Luh Supadmi. Pengaruh ...

terpengaruh terhadap lingkungan atau kelompok yang ada di sekitar mereka. Menurut (Santrock, 2007) mengatakan bahwa peran terpenting dari teman adalah sebagai sumber informasi mengenai dunia di luar keluarga, sumber kognitif, untuk pemecahan masalah dan perolehan pengetahuan, sumber emosional, untuk mengungkapkan ekspresi dan identitas diri. Adanya Komunitas dan Galeri Investasi Bursa Efek Indonesia di FEB Udayana saat ini diharapkan mampu menularkan minat investasi dikalangan mahasiswa yang mungkin dimulai dari beberapa orang yang mempunyai minat investasi yang nantinya akan mempengaruhi temannya baik secara langsung maupun tidak langsung. (Nagy, 1994) menyatakan bahwa saat ini investor sudah tidak lagi hanya mempertimbangkan faktor-faktor yang umum sebelum berinvestasi (misalnya tren harga saham), namun mereka mulai mempertimbangkan faktor-faktor lain. Ada lima faktor lain yang sudah mulai dipertimbangkan, yaitu accounting information, self imagelfirm image, coincidence, classic, social relevance, dan professional recommendation

Bursa Efek Indonesia (BEI) mencatat rekor dari sisi pertumbuhan jumlah investor saham sejak meluncurkan program kampanye "Yuk Nabung Saham" tiga tahun silam. Penambahan jumlah investor baru selama 2018 tercatat sebanyak 200.935 single investor identification (SID). Berdasarkan data PT Kustodian Sentral Efek Indonesia (KSEI), per tanggal 19 November 2018, total jumlah investor saham di BEI telah mencapai 829.426 SID. Jumlah tersebut meningkat 31,97 persen dibanding jumlah investor yang tercatat akhir 2017 sebanyak 628.491 SID. "Penambahan jumlah investor baru saham di BEI ini merupakan yang tertinggi sejak 38 tahun diresmikannya kembali Pasar Modal Indonesia," ujar Direktur Utama BEI Inarno Djajadi di Main Hall BEI (Tirto.id, 2018). Program kampanye "Yuk Nabung Saham" diluncurkan BEI pada 12 
November 2015. Selama 3 tahun terakhir tercatat ada penambahan 395.319 SID baru, atau hampir 2 kali lipat dari jumlah investor saham BEI dari sebelum kampanye "Yuk Nabung Saham" diluncurkan yakni 434.107 SID. Selain itu BEI juga memaparkan pertumbuhan jumlah investor baru per bulan lebih dari 19 ribu SID baru setiap bulan. Semua ini bisa terwujud karena BEI terus mengintensifkan kegiatan edukasi dan sosialisasi Pasar Modal yang jumlahnya di sepanjang tahun ini mencapai 5.027 kegiatan.

Mahasiswa yang telah menemukan minat berinvestasi, mereka dengan sungguh-sungguh akan memulai berinvestasi, berbeda jika seseorang tersebut tidak memiliki minat yang kuat dalam memulai berinvestasi. Penelitian yang dilakukan oleh (Triwijayati \& Koesworo, 2006) seseorang yang memiliki minat berinvestasi maka kemungkinan besar dia akan melakukan tindakan-tindakan yang dapat mencapai keinginan mereka untuk berinvestasi, seperti mengikuti seminar dan pelatihan investasi, mengikuti kelompok belajar, menerima dengan baik penawaran investasi, dan pada akhirnya melakukan investasi. Menjadi investor saat masih berada di lingkungan studi akan sangat memberikan keuntungan, diantaranya menabung untuk menjamin masa depan dan menabung untuk belajar dan mencari keuntungan (Kiyosaki \& Lechter, 2001).

Penelitan ini berlandaskan Theory of Planned Behavior yang menjelaskan manusia cenderung bertindak sesuai dengan persepsi pengendalian melalui perilaku tertentu, dimana intensi dipengaruhi oleh sikap terhadap perilaku, norma subjektif dan perceived behavior control. Theory of planned behavior merupakan teori yang dikembangkan oleh Ajzen yang merupakan penyempurnaan dari 
Ida Bagus Putu Pramana Putra dan Ni Luh Supadmi. Pengaruh ...

reason action theory yang dikemukakan oleh Fishbein dan Ajzen. Fokus utama dari teori planned behavior ini sama seperti teori reason action yaitu intensi individu untuk melakukan perilaku tertentu. Intensi dianggap dapat melihat faktor-faktor motivasi yang mempengaruhi perilaku. Intensi merupakan indikasi seberapa keras orang mau berusaha untuk mencoba dan berapa besar usaha yang akan dikeluarkan individu untuk melakukan suatu perilaku. Namun Ajzen berpendapat bahwa teori reason action belum dapat menjelaskan tingkah laku yang tidak sepenuhnya berada di bawah kontrol seseorang. Karena itu dalam theory of planned behavior Ajzen menambahkan satu faktor yang menentukan intensi yaitu perceived behavioral control.

Theory of Planned Behavior ini digunakan untuk menjelaskan manusia cenderung bertindak sesuai dengan intensi dan persepsi pengendalian melalui perilaku tertentu, dimana intensi dipengaruhi oleh tingkah laku, norma subjektif serta pengendalian perilaku. Penilaian dan pertimbangan calon investor muncul karena adanya kesadaran untuk bertindak. Sikap maupun pandangan seorang investor terhadap investasi saham bisai menjadi lebih kuat pada saat ia membuat keputusan untuk mencapai tiingkat stabilitas finansial tertentu, dimana rekomendasi dari keluarga, teman- teman dan lingkungannya akan membentuk pola perilaku tertentu bagi investor tersebut. Dalam penelitian ini perilaku yang dimaksud adalah minat berinvestasi saham seorang mahasiswa yang di pengaruhi oleh pelatihan pasar modal, persepsi mahasiswa, modal minimal dan hubungan pertemanan 
Penilaian dan pertimbangan calon investor muncul karena adanya kesadaran untuk bertindak. Ketika intensi untuk investasi sudah diperoleh, investor umumnya akan mulai mempertimbangkan berbagai faktor lain sebelum berinvestasi. Menurut (Hurlock, 1999), minat seseorang dapat ditumbuhkan dengan memberikan kesempatan bagi orang tersebut untuk belajar mengenai hal yang dia inginkan. Sejalan dengan Theory of Planned Behavior atau Reasoned Action (Ajzen \& Fishbein, 1975), aktifitas pembelajaran tersebut akan menyebabkan suatu perubahan sikap terhadap perilaku sebagai hasil dari pengalaman individu dalam interaksi dalam lingkungannya.

Pelatihan pasar modal dan seminar-seminar investasi khususnya mengenai pasar modal merupakan bentuk pembelajaran bagi individu yang terlibat yang kemudian akan menumbuhkan minat bagi individu tersebut. Pelatihan atau sosialisasi berpengaruh positif signifikan terhadap minat investor, dapat diinterpretasikan jika penyampaian sosialisasi mengenai efek-efek syariah di pasar modal dilakukan dengan tepat, maka mendorong investor untuk berinvestasi pada efek syariah (Khotimah, Warsini, \& Nuraeni, 2014) .Menurut (Tandio \& Widanaputra, 2016) pelatihan pasar modal berpengaruh positif signifikan pada variabel minat investasi

Dalam penelitian ini, peneliti memilih mahasiswa yang telah mengambil matakuliah pasar modal. Peneliti ingin melihat apakah dengan ditempuhnya mata kuliah tersebut, terdapat peningkatan minat investasi dalam diri mahasiswa. Peneliti juga ingin melihat pengaruh seminar dan pelatihan mengenasi pasar 
Ida Bagus Putu Pramana Putra dan Ni Luh Supadmi. Pengaruh ...

modal yang di ikuti diluar fakultas dalam mempengaruhi minat investasi. Berdasarkan pemaparan tersebut maka hipotesis yang dapat dirumuskan :

$\mathrm{H}_{1}$ : Pelatihan pasar modal berpengaruh positif terhadap minat berinvestasi di pasar modal

Menurut (Kotler \& Armstrong, 2008), persepsi adalah proses dimana orang memilih, mengatur, dan menginterpretasikan informasi untuk membentuk gambaran dunia yang berarti. Setiap orang tentunya memiliki persepsi berbeda terhadap suatu hal, termasuk tentang investasi. Begitu juga dengan mahasiswa yang memiliki persepsi yang berbeda akan investasi, mahasiswa yang memandang investasi sebagai hal yang tidak terlalu penting pada saat sekarang cenderung menggunakan uangnya untuk berperilaku konsumtif, berbeda dengan mahasiswa yang memandang investasi sebagai kebutuhan cenderung menyisihkan uangnya terlebih dahulu untuk ditabung atau berinvestasi.

Theory of planned behavior menyatakan secara umum, semakin individu memiliki evaluasi bahwa suatu perilaku akan menghasilkan konsekuensi positif maka individu akan cenderung bersikap favorable terhadap perilaku tersebut, semakin individu memiliki evaluasi negatif maka individu akan cenderung bersikap unfavorable terhadap perilaku tersebut (Ajzen, 2005). Pengambil keputusan investasi tidak selalu berperilaku dengan cara yang konsisten dengan asumsi yang dibuat sesuai dengan persepsi dan pemahaman atas informasi yang diterima (Christanti \& Mahastanti, 2011). Berdasarkan pemahaman diatas tentu juga ada hubungan antara persepsi mahasiswa dalam berinvestasi terhadap minat investasi. Berdasarkan uraian tersebut maka hipotesis yang dapat di rumuskan: 
$\mathrm{H}_{2}$ : Persespsi mahasiswa berpengaruh positif terhadap minat berinvestasi di pasar modal

Halim (2005) mengatakan bahwa penanaman modal disuatu perusahaan diharapkan akan memperoleh keuntungan pada masa yang akan datang. Menurut penelitian (Wibowo \& Purwohandoko, 2018) modal minimal merupakan setoran awal untuk membuka rekening saat pertama kali pada pasar modal. Kebijakan modal minimal merupakan batas minimal setoran modal awal untuk membuka akun rekening efek yang telah ditetapkan oleh perusahaan sekuritas. Penelitian (Christanti \& Mahastanti, 2011) menunjukan bahwa sebelum berinvestasi investor akan memikirkan beberapa faktor, contohnya yaitu personal financial needs.

Dalam Theory of planned behavior perilaku individu dapat dipengaruhi oleh perceived behavioral control yaitu mengenai kemudahan atau kesulitan untuk melakukan perilaku tertentu (Ajzen, 2005). Perceived behavioral control ditentukan oleh kombinasi antara control belief dan perceived power control. Control belief merupakan belief individu mengenai faktor pendukung atau penghambat untuk memunculkan sebuah perilaku. Syarat berinvestasi di pasar modal saat ini semakin mudah, salah satunya adalah modal minimal untuk berinvestasi adalah Rp.100.000, sehingga sangat memungkinkan bagi mahasiswa untuk berinvestasi di pasar modal. (Nisa \& Zulaika, 2017) menemukan adanya pengaruh antara modal minimal terhadap minat investasi, jika modal minimal yang ditentukan memiliki nilai yang kecil, maka akan cenderung menumbuhkan minat berinvestasi bagi para mahasiswa. Berdasarkan uraian tersebut maka hipotesis yang dapat di rumuskan: 
Ida Bagus Putu Pramana Putra dan Ni Luh Supadmi. Pengaruh ...

$\mathrm{H}_{3}$ : Modal minimal berpengaruh negatif terhadap minat berinvestasi di pasar modal

Theory of planned behavior (Ajzen, 2005) mendefinisikan norma subjektif sebagai persepsi individu tentang tekanan sosial untuk melakukan atau tidak melakukan suatu perilaku. Norma subjektif ditentukan oleh normative belief dan motivation to comply. Normative belief adalah belief mengenai setuju atau tidaknya suatu perilaku yang berasal dari kelompok di sekitar individu. Motivation to comply adalah motivasi individu untuk mematuhi harapan. Menurut Harker dan Wright (Desmita, 2009) Masyarakat lebih banyak berada di luar rumah bersama dengan teman-teman sebaya sebagai kelompok. Pengaruh teman-teman sebaya pada sikap, pembicaraan, minat, penampilan dan perilaku terkadang lebih besar daripada pengaruh keluarga. Mahasiswa ketika memiliki hubungan pertemanan dengan orang yang melakukan investasi di pasar modal maka mahasiswa tersebut dapat memiliki minat untuk berinvestasi di pasar modal.

Dari uraian tersebut maka dapat diketahui bahwa teman sebagai lingkungan sosial bagi seseorang yang mempunyai peranan cukup penting bagi perkembangan kepribadiannya. Maka hipotesis yang dapat di rumuskan:

$\mathrm{H}_{4}$ : Hubungan pertemanan berpengaruh positif terhadap minat berinvestasi di pasar modal

\section{METODE PENELITIAN}

Penelitian ini dilakukan di kampus Fakultas Ekonomi dan Bisnis Universitas Udayana. Objek penelitian dalam penelitian ini adalah pelatihan pasar modal, 
persepsi mahasiswa, modal minimal, hubungan pertemanan dan minat berinvestasi mahasiswa. Populasi yang digunakan dalam penelitian ini adalah seluruh mahasiswa jurusan Akuntansi yang saat ini terdaftar di Fakultas Ekonomi dan Bisnis Universitas Udayana angkatan 2015 berjumlah 349 orang.

Kriteria yang digunakan untuk menentukan sampel dalam penelitian ini adalah mahasiswa yang telah menempuh mata kuliah teori pasar modal dan semester 7 pada tahun akademik 2015/2016 yang masih aktif kuliah dengan alasan bahwa selama 6 semester mahasiswa menempuh pendidikan di Fakultas Ekonomi dan Bisnis tentunya tidak lepas dari hubungan dengan teman-teman yang relatif lama yang dapat mempengaruhi minat, sikap dan perilaku Karena jumlah mahasiswa yang memenuhi syarat sangat besar, maka digunakan rumus Slovin dalam menentukan sampelnya, yaitu:

$n=\frac{N}{1+N e^{2}}$

$\mathrm{n} \quad=$ jumlah sampel

$\mathrm{N} \quad=$ jumlah populasi

e $\quad=$ Toleransi kesalahan yang dipilih $(10 \%)$

Perhitungan sampel sebagai berikut:

$$
\begin{aligned}
& n=\frac{298}{1+298\left(0,1^{2}\right)} \\
& n=74,8 \text { dibulatkan } 75
\end{aligned}
$$

Teknik analisis data yang digunakan dalam penelitian ini adalah analisis regresi linier berganda. Formula yang digunakan dengan rumus:

$\mathrm{Y}=\alpha+\beta_{1} \mathrm{X}_{1}+\beta_{2} \mathrm{X}_{2}+\beta_{3} \mathrm{X}_{3}+\beta_{4} \mathrm{X}_{4}+e$ 
Keterangan:

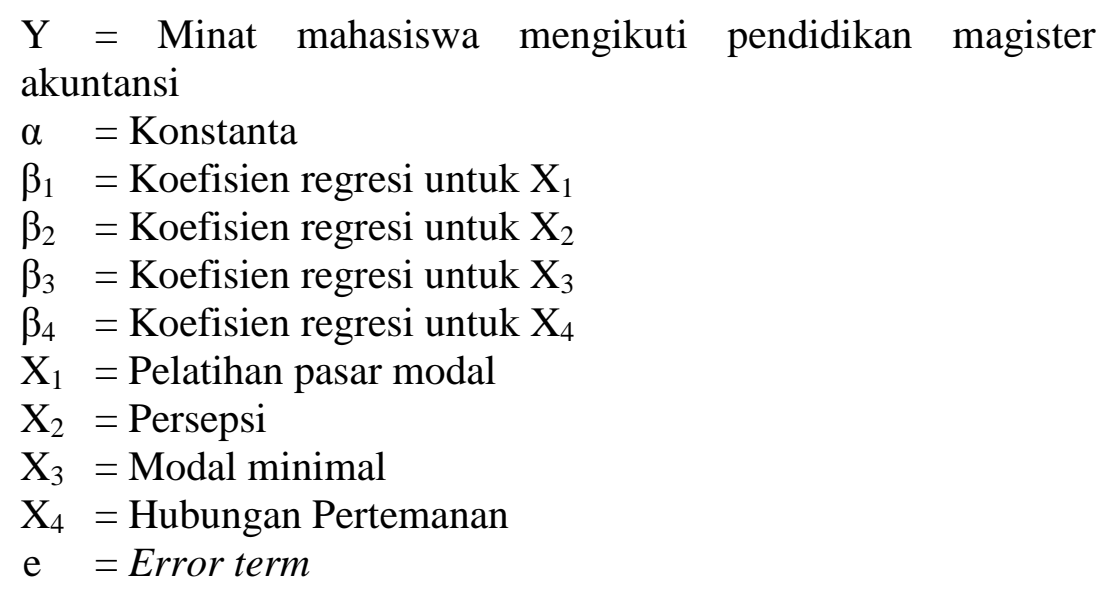

\section{HASIL DAN PEMBAHASAN}

Data penelitian dikumpulkan dengan menyebarkan kuesioner dengan cara memberikan pertanyaan kuesioner secara online dengan menggunakan google formulir kepada mahasiswa akuntansi Fakultas Ekonomi dan Bisnis Universitas Udayana di Bali. Penyebaran kuesioner dimulai dari 11 Desember sampai dengan 18 Desember 2018. Kuesioner yang disebar oleh peneliti sebanyak 75 kuesioner. Dari keseluruhan kuesioner yang disebar melalui google formulir, kuesioner sebanyak 75 secara keseluruhan dijawab oleh responden.

Jenis kelamin responden dapat digunakan sebagai suatu acuan ketegasan dan keterlibatan yang mempengaruhi emosi untuk mengambil suatu keputusan. Berdasarkan Tabel 1 dapat dilihat bahwa sebagian besar responden penelitian ini adalah laki-laki yaitu sebanyak 44 orang 58,6 persen dan perempuan sebanyak 31 orang 41,4 persen. Angkatan responden digunakan sebagai indikator untuk mengetahui tingkat pengetahuan dan intelektualitas yang dimiliki oleh responden. 
Berdasarkan Tabel 1 dapat dilihat bahwa angkatan 2015 sebanyak 75 orang responden $(100 \%)$

Tabel 1.

Karakteristik responden

\begin{tabular}{|c|c|c|c|}
\hline \multirow[t]{2}{*}{ No. } & \multirow[t]{2}{*}{ Karakteristik Responden } & \multicolumn{2}{|c|}{ Jumlah } \\
\hline & & Orang & Persentase $(\%)$ \\
\hline \multirow[t]{4}{*}{1.} & Jenis Kelamin & & \\
\hline & Laki-laki & 44 & 58,6 \\
\hline & Perempuan & 31 & 41,1 \\
\hline & Total & 75 & 100 \\
\hline \multirow[t]{3}{*}{2} & Angkatan & & \\
\hline & 2015 & 75 & 100 \\
\hline & Total & 75 & 100 \\
\hline
\end{tabular}

Sumber: Data diolah, 2018

Anaslisis statistik deskriptif digunakan untuk mendeskripsikan nilai minimum (minimum), rata-rata (mean), nilai maksimum (maximum) dan standar deviasi (std. deviation). Berikut adalah tabel hasil analisis statistik deskriptif.

Tabel 2.

Hasil Statistik Deskriptif

\begin{tabular}{lcrrrr}
\hline \multicolumn{1}{c}{ Variabel } & N & Min. & Max. & Mean & Std. Deviasi \\
\hline Pelatihan Pasar Modal $\left(\mathrm{X}_{1}\right)$ & 75 & 6 & 20 & 17,46 & 2,987 \\
Persepsi Mahasiswa $\left(\mathrm{X}_{2}\right)$ & 75 & 12 & 24 & 20,04 & 3,033 \\
Modal Minimal $\left(\mathrm{X}_{3}\right)$ & 75 & 4 & 16 & 13,72 & 2,178 \\
Hubungan Pertemanan $\left(\mathrm{X}_{4}\right)$ & 75 & 12 & 24 & 19,90 & 3,150 \\
Minat Berinvestasi (Y) & 75 & 16 & 32 & 27,29 & 4,707 \\
\hline Sumber: Data diolah, 2018 & & & & &
\end{tabular}

Pelatihan Pasar Modal $\left(\mathrm{X}_{1}\right)$ memiliki nilai minimum sebesar 6 dan nilai maksimum sebesar 20 nilai rata-rata sebesar 17,46. Nilai rata-rata 17,46 menunjukkan bahwa respon responden dalam menjawab pernyataan pada kuesioner cenderung merasa setuju pada masing-masing item pernyataan artinya pelatihan pasar modal cenderung tinggi. Standar deviasi pada variabel pelatihan pasar modal adalah sebesar 2,987. Hal ini menunjukkan bahwa standar penyimpangan data terhadap nilai rata-ratanya adalah 2,987 
Ida Bagus Putu Pramana Putra dan Ni Luh Supadmi. Pengaruh ...

Persepsi Mahasiswa $\left(\mathrm{X}_{2}\right)$ memiliki nilai minimum sebesar 12 dan nilai maksimum sebesar 24 nilai rata-rata sebesar 20,04. Nilai rata-rata 20,04 menunjukkan bahwa respon responden dalam menjawab pernyataan pada kuesioner cenderung merasa setuju pada masing-masing item pernyataan artinya persepsi mahasiswa cenderung tinggi. Standar deviasi pada variabel persepsi mahasiswa adalah sebesar 3,033. Hal ini menunjukkan bahwa standar penyimpangan data terhadap nilai rata-ratanya adalah 3,033

Modal Minimal $\left(\mathrm{X}_{3}\right)$ memiliki nilai minimum sebesar 4 dan nilai maksimum sebesar 16 nilai rata-rata sebesar 13,72. Nilai rata-rata 13,72 menunjukkan bahwa respon responden dalam menjawab pernyataan pada kuesioner cenderung merasa setuju pada masing-masing item pernyataan artinya modal minimal cenderung tinggi. Standar deviasi pada variabel modal minimal adalah sebesar 2,178. Hal ini menunjukkan bahwa standar penyimpangan data terhadap nilai rata-ratanya adalah 2,178.

Hubungan Pertemanan $\left(\mathrm{X}_{4}\right)$ memiliki nilai minimum sebesar 12 dan nilai maksimum sebesar 24 nilai rata-rata sebesar 19,90. Nilai rata-rata 19,90 menunjukkan bahwa respon responden dalam menjawab pernyataan pada kuesioner cenderung merasa setuju pada masing-masing item pernyataan artinya hubungan pertemanan cenderung tinggi. Standar deviasi pada variabel hubungan pertemanan adalah sebesar 3,150. Hal ini menunjukkan bahwa standar penyimpangan data terhadap nilai rata-ratanya adalah 3,150 .

Minat Berinvestasi (Y) memiliki nilai minimum sebesar 16 dan nilai maksimum sebesar 32 nilai rata-rata sebesar 27,29. Nilai rata-rata 27,29 
menunjukkan bahwa respon responden dalam menjawab pernyataan pada kuesioner cenderung merasa setuju pada masing-masing item pernyataan artinya minat berinvestasi cenderung tinggi. Standar deviasi pada minat berinvestasi adalah sebesar 4,702. Hal ini menunjukkan bahwa standar penyimpangan data terhadap nilai rata-ratanya adalah 4,702 .

Perhitungan koefisien regresi linier berganda dilakukan dengan analisis regresi melalui software SPSS 18.0 for Windows, Hasil analisis disajikan pada Tabel 3 berikut.

Tabel 3.

Hasil Analisis Regresi Linier Berganda

\begin{tabular}{llccccc}
\hline Model & \multicolumn{2}{c}{ Unstandardized } \\
& & \multicolumn{2}{c}{$\begin{array}{c}\text { Standardized } \\
\text { Coefficients }\end{array}$} & Coefficients & & \\
& & B & Std. Error & Beta & T & Sig. \\
\hline 1 & (Constant) & 0,987 & 2,111 & & 0,467 & 0,642 \\
& Pelatihan Pasar Modal & 0,276 & 0,117 & 0,175 & 2,358 & 0,021 \\
& Persepsi Mahasiswa & 0,635 & 0,168 & 0,409 & 3,777 & 0,000 \\
& Modal Minimal & $-0,241$ & 0,119 & $-0,112$ & $-2,031$ & 0,046 \\
& Hubungan Pertemanan & 0,606 & 0,161 & 0,405 & 3,752 & 0,000 \\
& R Square & 0,803 & & & & \\
& F Statistik & 71,230 & & & & \\
& Signifikansi Uji F & 0,000 & & & &
\end{tabular}

Berdasarkan hasil analisis regresi linier berganda seperti yang disajikan pada Tabel 3, maka dapat dibuat persamaan regresi sebagai berikut:

$$
\hat{Y}=0,987+0,276 X 1+0,635 X 2-0,241 X 3+0,606 X 4)
$$

Nilai konstanta sebesar 0,987 hal ini berarti bahwa bila asumsikan nilai. Pelatihan Pasar Modal, Persepsi Mahasiswa, Modal Minimal dan Hubungan Pertemanan sama dengan nol maka Minat Berinvestasi Sebesar sebesar 0,987 satuan. Nilai koefisien regresi PPM sebesar 0,276 memiliki arti jika PPM meningkat sebesar 1 satuan, maka Minat Beinvestasi akan meningkat sebesar 0,276 satuan dengan asumsi semua variabel independen lainnya konstan. Nilai 
Ida Bagus Putu Pramana Putra dan Ni Luh Supadmi. Pengaruh ...

koefisien regresi Persepsi mahasiswa sebesar 0,635 memiliki arti jika Persepsi mahasiswa meningkat sebesar 1 satuan, maka Minat Berinvestasi akan meningkat sebesar 0,635 satuan dengan asumsi semua variabel independen lainnya konstan. Nilai koefisien regresi Modal Minimal sebesar -0,241 memiliki arti jika Modal Minimal menurun sebesar 1 satuan, maka Minat berinvestasi akan meningkat sebesar -0,241 satuan dengan asumsi semua variabel independen lainnya konstan. Nilai koefisien regresi Hubungan Pertemanan sebesar 0,606 memiliki arti jika Hubungan Pertemanan meningkat sebesar 1 satuan, Minat Berinvestasi akan meningkat sebesar 0,606 satuan dengan asumsi semua variabel independen lainnya konstan.

Uji ketepatan model regresi bertujuan untuk mengetahui apakah semua variabel bebas yang diidentifikasi (pelatihan pasar modal, persepsi mahasiswa, modal minimal, dan hubungan pertemanan) tepat digunakan memprediksi minat berinvestasi. Uji ini sering juga disebut dengan uji F. Hasil pengolahan data pada Lampiran 9 dengan menggunakan program SPSS diperoleh nilai $F_{\text {hitung }}$ sebesar 71,230, dengan nilai sig. $0,000<0,05$, maka Ho ditolak dan $\mathrm{H}_{1}$ diterima. Kesimpulannya, pada kelompok yang diuji memiliki perbedaan yang nyata (signifikan). Hasil ini mempunyai arti bahwa ada pengaruh signifikan antara faktor Pelatihan pasar modal, Persepsi mahasiswa, Modal minimal, dan Hubungan pertemanan pada terhadap Minat berinvestasi.

Besarnya pengaruh variabel bebas terhadap variabel terikat yang ditunjukkan oleh nilai determinasi total (R Square) sebesar 0,803 mempunyai arti bahwa sebesar 80,3 persen variasi Minat berinvestasi dipengaruhi oleh variasi 
Pelatihan pasar modal (X1), Persepsi mahasiswa (X2), Modal minimal (X3), dan Hubungan pertemanan (X4) mampu menjelaskan 80,3 persen variabel dependen (Minat berinvestasi) sedangkan sisanya sebesar 19,7 persen dijelaskan oleh faktor lain yang tidak dimasukan ke dalam model penelitian ini.

Pengaruh variabel pelatihan pasar modal, persepsi mahasiswa, modal minimal, dan hubungan pertemanan terhadap minat berinvestasi diuji dengan menggunakan Uji t. Kriteria pengujian untuk menjelaskan interpretasi pengaruh antar masing-masing variabel yakni apabila nilai signifikansi $<0,05$ maka $\mathrm{H}_{0}$ ditolak dan $\mathrm{H}_{1}$ diterima. Sebaliknya, jika nilai signifikansi > 0,05 maka $\mathrm{H}_{0}$ diterima dan $\mathrm{H}_{1}$ ditolak.

Berdasarkan hasil analisis pengaruh pelatihan pasar modal terhadap minat berinvestasi diperoleh nilai Signifikasi sebesar 0,021 dengan nilai koefisien regresi positif sebesar 0,276. Nilai Signifikansi 0,021 < 0,050 mengindikasikan bahwa $\mathrm{H}_{0}$ ditolak dan $\mathrm{H}_{1}$ diterima. Hasil ini mempunyai arti bahwa pelatihan pasar modal berpengaruh positif dan signifikan terhadap minat berinvestasi. Hipotesis pertama dari penelitian ini menyatakan bahwa Pelatihan pasar modal berpengaruh positif pada minat berinvestasi. Setelah dilakukannya pengujian, hasil penelitian menunjukkan bahwa nilai koefisien regresi positif sebesar 0,276. Hal ini menunjukkan bahwa variabel pelatihan pasar modal berpengaruh positif pada minat berinvestasi, maka hipotesis $\left(\mathrm{H}_{1}\right)$ diterima. Berarti bahwa semakin sering seseorang mengikuti pelatihan pasar modal dan paham maka minat berinvestasi semakin tinggi. Dengan demikian hasil tersebut sesuai dengan Theory of Planned Behavior dimana seseorang mempunyai minat untuk 
Ida Bagus Putu Pramana Putra dan Ni Luh Supadmi. Pengaruh ...

berinvestasi akan cenderung melaksanakan tindakan supaya keinginan dari seseorang tersebut dapat tercapai. Dapat diartikan bahwa seseorang yang telah mengikuti berbagai pelatihan pasar modal akan cenderung melakukan investasi, karena dari pelatihan tersebut seseorang akan mendapat ilmu baru serta mendapat inspirasi atau saran untuk berinvestasi. Ilmu, wawasan, inspirasi serta saran tersebut dapat diterapkan secara riil dalam investasinya agar keinginan dalam berinvestasi dapat terwujud. Keinginan dalam investasi tersebut menandakan bahwa seseorang tersebut tertarik untuk berinvestasi di pasar modal. apabila seseorang tersebut sering mengikuti berbagai pelatihan pasar modal, maka semakin tinggi minat seseorang untuk melakukan investasi di pasar modal. Hasil Penelitian ini sejalan dengan hasil penelitian (Tandio \& Widanaputra, 2016) dan (Khotimah et al., 2014) yang menyatakan pelatihan pasar modal dan sosialisasi berpengaruh positif signifikan terhadap minat investor, dapat diinterpretasikan jika penyampaian sosialisasi mengenai efek-efek di pasar modal dilakukan dengan tepat, maka mendorong investor untuk berinvestasi.

Berdasarkan hasil analisis pengaruh persepsi mahasiswa terhadap minat berinvestasi diperoleh nilai signifikansi sebesar 0,000 dengan nilai koefisien regresi positif sebesar 0,635 . Nilai Signifikansi $0,000<0,05$ mengindikasikan bahwa $\mathrm{H}_{0}$ ditolak dan $\mathrm{H}_{2}$ diterima. Hasil ini mempunyai arti bahwa persepsi mahasiswa berpengaruh positif dan signifikan terhadap minat berinvestasi. Hipotesis kedua $\left(\mathrm{H}_{2}\right)$ menyatakan bahwa Persepsi Mahasiswa berpengaruh positif pada minat berinvestasi. Setelah dilakukannya pengujian, hasil penelitian menunjukkan bahwa nilai koefisien regresi sebesar 0,635. Hal ini menunjukkan 
bahwa variabel persepsi mahasiwa berpengaruh positif pada minat berinvestasi , maka hipotesis $\left(\mathrm{H}_{2}\right)$ diterima. Berarti bahwa semakin seorang mahasiswa menganggap investasi penting dan perlu untuk dilakukan berarti semakin tinggi minat berinvestasi. Persepsi mahasiswa disini menganggap investasi sebagai hal yang penting dan bermanfaat. Sesuai dengan Theory of planned behavior menyatakan secara umum, semakin individu memiliki evaluasi bahwa suatu perilaku akan menghasilkan konsekuensi positif maka individu akan cenderung bersikap favorable terhadap perilaku tersebut sebaliknya, semakin individu memiliki evaluasi negatif maka individu akan cenderung bersikap unfavorable terhadap perilaku tersebut (Ajzen, 2005). Pengambil keputusan investasi tidak selalu berperilaku dengan cara yang konsisten dengan asumsi yang dibuat sesuai dengan persepsi dan pemahaman atas informasi yang diterima (Christanti \& Mahastanti, 2011)

Berdasarkan hasil analisis pengaruh modal minimal terhadap minat berinvestasi diperoleh nilai signifikansi sebesar 0,046 dengan nilai koefisien regresi negatif sebesar $-0,241$. Nilai signifikansi $0,046<0,050$ mengindikasikan bahwa $\mathrm{H}_{0}$ ditolak dan $\mathrm{H}_{3}$ diterima. Hasil ini mempunyai arti bahwa modal minimal berpengaruh negatif dan signifikan terhadap minat berinvestasi. Hipotesis ketiga $\left(\mathrm{H}_{3}\right)$ menyatakan bahwa Modal minimal berpengaruh negatif terhadap Minat investasi. Setelah dilakukan pengujian, hasil penelitian menunjukkan bahwa nilai koefisien regresi negatif sebesar -0,241. Hal ini menunjukkan bahwa Modal minimal berpengaruh negatif pada Minat berinvestasi, maka hipotesis $\left(\mathrm{H}_{3}\right)$ diterima. Berarti bahwa semakin kecil modal 
minimal yang ditetapkan untuk bisa investasi maka semakin besar minat untuk berinvestasi. Hasil penelitian ini mendukung Theory of Planned Behavior (Ajzen, 1991) dimana sikap dari individu seseorang akan mempengaruhi minat seseorang dalam kemampuannya untuk mengambil keputusan yang ingin dilakukannya. Di era modern ini, investasi tidak memerlukan biaya yang tinggi, cukup dengan memenuhi modal minimal yang telah ditetapkan. Dengan adanya modal minimal tersebut membuat seseorang melakukan investasi. Investasi tersebut dapat dipengaruhi oleh sikap individu, dimana modal minimal tersebut dirasa cukup murah dan para responden mampu memenuhi (membayar) modal minimal yang ditetapkan, sehingga berminat untuk berinvestasi apabila semakin baik dalam arti murah dan terjangkau atas harga (nominal modal minimal investasi) yang diberikan atas investasi maka minat akan investasi semakin besar. Hasil penelitian ini sejalan dengan (Nisa \& Zulaika, 2017) dan (Wibowo \& Purwohandoko, 2018) yang menunjukkan bahwa mahasiswa akan cenderung melakukan investasi apabila modal minimal untuk berinvestasi semakin kecil Berdasarkan hasil analisis pengaruh hubungan pertemanan terhadap minat berinvestasi diperoleh nilai signifikansi sebesar 0,000 dengan nilai koefisien regresi positif sebesar 0,606 . Nilai signifikansi $0,000<0,05$ mengindikasikan bahwa $\mathrm{H}_{0}$ ditolak dan $\mathrm{H}_{4}$ diterima. Hasil ini mempunyai arti bahwa hubungan pertemanan berpengaruh positif dan signifikan terhadap minat berinvestasi. Hipotesis keempat $\left(\mathrm{H}_{4}\right)$ menyatakan bahwa Hubungan pertemanan berpengaruh positif pada minat berinvestasi . Setelah dilakukan pengujian, hasil penelitian menunjukkan bahwa nilai koefisien regresi sebesar 0,606. Hal ini menunjukkan 
bahwa hubungan pertemanan berpengaruh positif pada minat investasi, maka hipotesis $\left(\mathrm{H}_{4}\right)$ diterima. Berarti bahwa semakin banyak dan sering seseorang dengan lingkungan teman yang berinvestasi maka semakin besar minat untuk berinvestasi. Dalam Theory of planned behavior (Ajzen, 2005) mendefinisikan norma subjektif sebagai persepsi individu tentang tekanan sosial untuk melakukan atau tidak melakukan suatu perilaku. Norma subjektif ditentukan oleh normative belief dan motivation to comply. Normative belief adalah belief mengenai kesetujuan atau ketidaksetujuan yang berasal dari kelompok di sekitar individu. Motivation to comply adalah motivasi individu untuk mematuhi harapan. Hal ini berarti bahwa ketika seorang individu memiliki hubungan pertemanan dengan orang yang melakukan investasi di pasar modal maka seseorang tersebut dapat memiliki minat untuk berinvestasi di pasar modal sejalan dengan hasil penelitian (Pranyoto \& Siregar, 2015) dapat diketahui bahwa teman sebagai lingkungan sosial bagi seseorang yang mempunyai peranan cukup penting bagi perkembangan kepribadiannya. Teman memberikan sebuah dunia tempat seseorang melakukan sosialisasi dalam suasana yang mereka ciptakan sendiri.

Hasil penelitian ini diharapkan dapat memberikan tambahan informasi mengenai pengaruh pelatihan pasar modal, persepsi mahasiswa, modal minimal dan hubungan pertemanan pada minat berinvestasi mahasiswa akuntansi Unud. Menambah informasi berkaitan dengan theory of planned behavior. Terdapat bukti empiris bagi peneliti dalam pelatihan pasar modal, persepsi mahasiswa, 
Ida Bagus Putu Pramana Putra dan Ni Luh Supadmi. Pengaruh ...

modal minimal dan hubungan pertemanan pada minat berinvestasi mahasiswa akuntansi UNUD.

Hasil penelitian ini diharapkan dapat menambah wawasan pada para pembaca, khususnya mahasiswa bahwa mereka sejak dini agar bijak dalam mengelola keuangan, mengimplementasikan ilmu yang di dapat, dan berani berinvestasi langsung ke pasar modal karena dengan usia yang masih muda banyak waktu yang bisa digunakan untuk belajar dan berinvestasi. Tentu dengan berinvestasi yang benar seseorang dapat mengembangkan aset dan melawan inflasi, terlebih lagi ikut berkontribusi dalam pembangunan Negara, untuk FEB UNUD penelitian ini dapat dijadikan bahan evaluasi agar bisa memfasilitasi minat mahasiswa dalam hal berinvestasi di pasar modal, dosen-dosen teori pasar modal, galeri investasi dan komunitas investor agar bersinergi dalam menumbuhkan minat investasi di lingkungan kampus terlebih bisa membawa ke masyarakat luas.

\section{SIMPULAN}

Pelatihan pasar modal berpengaruh positif pada minat berinvestasi. Hal ini berarti bahwa semakin sering seseorang mengikuti pelatihan pasar modal dan paham maka semakin besar minat untuk berinvestasi. Persepsi mahasiswa berpengaruh positif pada minat berinvestasi. Hal ini berarti bahwa semakin seorang mahasiswa menganggap investasi sebagai hal yang penting dan perlu untuk dilakukan maka semakin besar minat untuk berinvestasi. Modal minimal berpengaruh negatif pada minat berinvestasi. Hal ini berarti bahwa semakin kecil modal minimal yang ditetapkan untuk bisa berinvestasi maka semakin besar minat untuk berinvestasi. 
Hubungan pertemanan berpengaruh positif pada minat berinvestasi. Hal ini berarti bahwa semakin banyak seseorang yang memiliki teman dengan lingkungan yang berinvestasi di pasar modal maka semakin besar minat untuk berinvestasi.

Peneliti menyarankan untuk penelitian selanjutnya dapat mempertimbangkan wilayah penelitian yang lebih luas dan menambahkan variabel lainnya sehingga dapat mengetahui faktor lain yang dapat mempengaruhi minat investasi selain faktor yang digunakan dalam penelitian ini, seperti faktor informasi ekonomi dan akuntansi, literasi keuangan, penghasilan dan lain-lain.

\section{REFERENSI}

Ajzen, I. (1991). The Theory Planned Behavior. Organizational Behavior and Human Decision Processes, 50, 179-211.

Ajzen, I. (2005). Attitudes, Personality and Behavior (2nd ed.). Berkshire: McGraw-Hill Professional Publishing.

Ajzen, I., \& Fishbein, M. (1975). Belief, Attitude, Intention, and Behavior: An Introduction to Theory and Research. Addison-Wesley, 129-385.

BEI. 2018. Yuk Nabung Saham https://yuknabungsaham.idx.co.id/, diakses tanggal 21 Oktober 2018)

Christanti, N., \& Mahastanti, L. A. (2011). Faktor-Faktor yang Dipertimbangkan Investor dalam Melakukan Investasi. Jurnal Manajemen Teori Dan Terapan I.

Desmita. (2009). Psikologi Perkembangan. Bandung: PT Remaja Rosdakarya.

Halim, A. (2005). Analisis Investasi (2nd ed.). Jakarta: Salemba Empat.

Hurlock, E. . (1999). Psikologi Perkembangan: Suatu Pendekatan Sepanjang Rentang Kehidupan. (Istiwidayati \& Soedjarwo, Eds.) (5th ed.). Jakarta: Erlangga. 
Khotimah, H., Warsini, S., \& Nuraeni, Y. (2014). Pengaruh Sosialisasi dan Pengetahuan Terhadap Minat Investor Pada Efek Syariah di Pasar Modal (Survei Pada Nasabah PT Danareksa Sekuritas Cabang FE-UI Depok), 423433.

Kiyosaki, R. T., \& Lechter, S. L. (2001). Cashflow Quadrant. Jakarta: Gramedia Pustaka Utama.

Kotler, P., \& Armstrong, G. (2008). Prinsip-Prinsip Pemasaran (12th ed.). Jakarta: Erlangga.

Mumtaz, F. (2010). Investasi: Keinginan atau Kebutuhan? Jakarta: Salemba Empat.

Nagy, R. . (1994). Factors Influencing Individual Investor Behavior. Retrieved from http:/www.proquest.com

Nisa, A., \& Zulaika, L. (2017). Pengaruh Pemahaman Investasi, Modal Minimal Investasi Dan Motivasi Terhadap Minat Mahasiswa Berinvestasi Di Pasar Modal. Jurnal PETA, 2(2).

Pranyoto, E., \& Siregar, N. Y. (2015). Literasi Ekonomi, Hubungan Pertemanan, Sikap, Norma dan Kontrol Diri Terhadap Minat Masyarakat Lampung Untuk Berinvestasi di Pasar Modal. Jurnal Manajemen Dan Bisnis, 5(2), 196-216.

Rooij, M. Van, Lusardi, A., \& Alessie, R. (2011). Financial literacy and stock market participation. Journal of Financial Economics, 101(2), 449-472.

Santrock, J. . (2007). Perkembangan Anak Edisi Kesebelas. (M. Rachmawati, Ed.) (2nd ed.). Jakarta: Erlangga.

Sunariyah. (2011). Pengantar Pengetahuan Pasar Modal (6th ed.). Yogyakarta: UPP STIM YKPN.

Tandelilin, E. (2010). Portofolio dan Investasi Teori dan Aplikasi (1st ed.). Yogyakarta: Kanisius.

Tandio, T., \& Widanaputra, A. A. G. P. (2016). Pengaruh Pelatihan Pasar Modal, Return, Persepsi Risiko, Gender, dan Kemajuan Tekonologi Pada Minat Investasi Mahasiswa, 16, 2316-2341.

Tipisnya Jumlah Investor Pasar Modal Indonesia. https://tirto.id/tipisnya-jumlahinvestor-pasar-modal-indonesia-cHXg diakses pada tanggal 22 November 2018 
Triwijayati, A., \& Koesworo, Y. (2006). Minat Berinvestasi Mahasiswa Akuntansi. Jurnal Widya Manajemen Dan Akuntansi, 6(1), 17-41.

Wibowo, A., \& Purwohandoko. (2018). Pengaruh Pengetahuan Investasi, Kebijakan Modal Minimal Investasi, dan Pelatihan Pasar Modal Terhadap Minat Investasi. Jurnal Ilmu Manajemen, 7(1), 192-201. 